Jewish Life in Small-Town America 


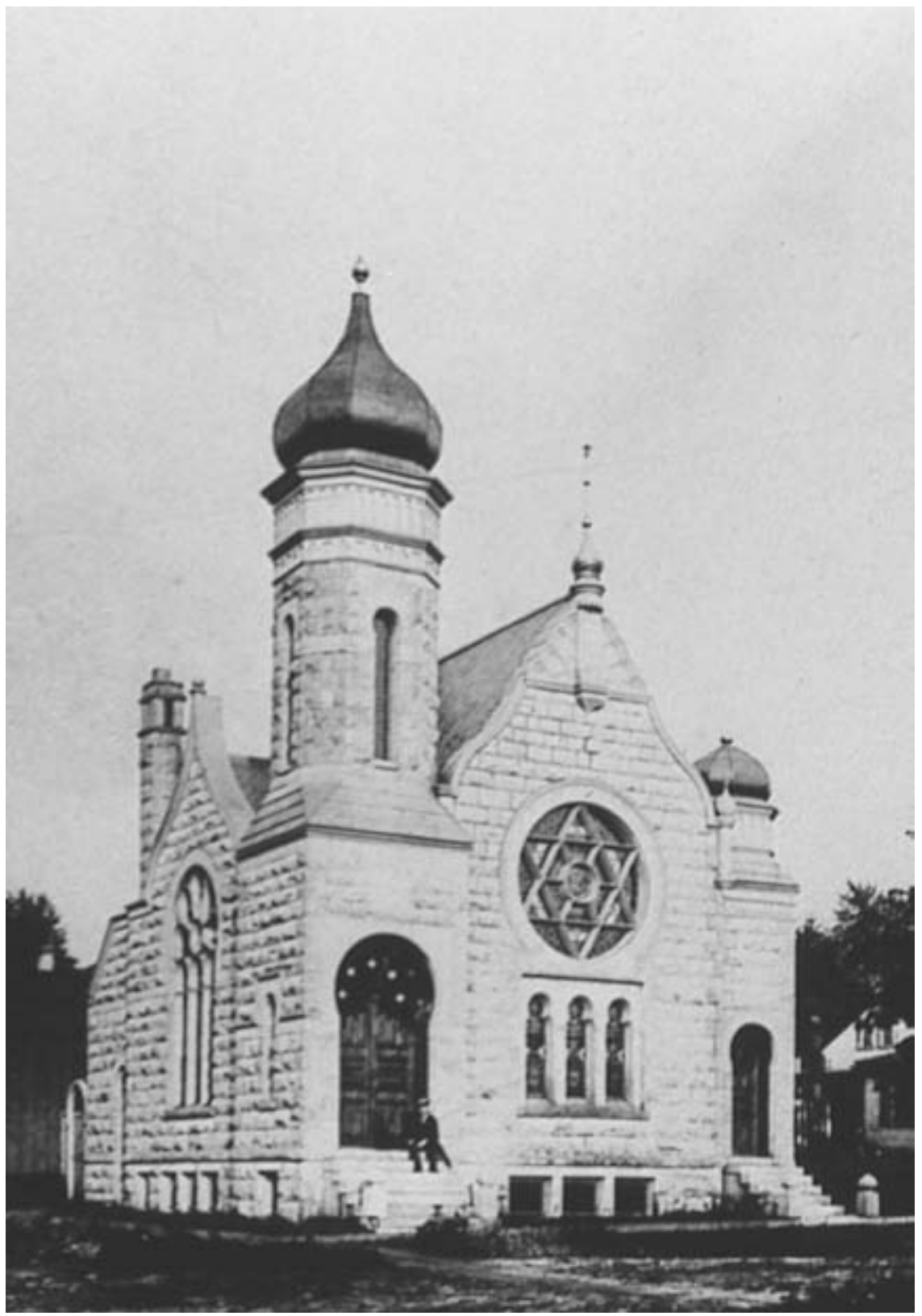

The Moses Montefiore Temple in Bloomington, Illinois, ca. 1889. Courtesy of the Jacob Rader Marcus Center of the American Jewish Archives. 


\title{
Jewish Life in Small-Town America: A History
}

\author{
Lee Shai Weissbach
}

Yale University Press

New Haven \& London 
Published with assistance from the Committee on Academic Publications of the University of Louisville.

Copyright () 2005 by Yale University. All rights reserved. This book may not be reproduced, in whole or in part, including illustrations, in any form (beyond that copying permitted by Sections 107 and 108 of the U.S. Copyright Law and except by reviewers for the public press), without written permission from the publishers.

Designed by Mary Valencia.

Set in Veljovic type by Keystone Typesetting, Inc.

Printed in the United States of America by Sheridan Books.

Library of Congress Cataloging-in-Publication Data

Weissbach, Lee Shai, 1947-

Jewish life in small-town America : a history / Lee Shai Weissbach.

p. cm.

Includes bibliographical references and index.

ISBN 0-300-10671-8 (alk. paper)

1. Jews-United States-Social conditions-19th century. 2. Jews-United StatesSocial conditions-20th century. 3. Cities and towns-Religious aspects-Judaism.

4. City and town life-United States-History. 5. United States-History, Local. I. Title. E184.36.S65W45 2005

$307.76^{\prime} 2^{\prime} 089924073-d c 22$

2004051195

A catalogue record for this book is available from the British Library.

The paper in this book meets the guidelines for permanence and durability of the Committee on Production Guidelines for Book Longevity of the Council on Library Resources.

$\begin{array}{llllllllll}10 & 9 & 8 & 7 & 6 & 5 & 4 & 3 & 2 & 1\end{array}$ 
For Sharon 
